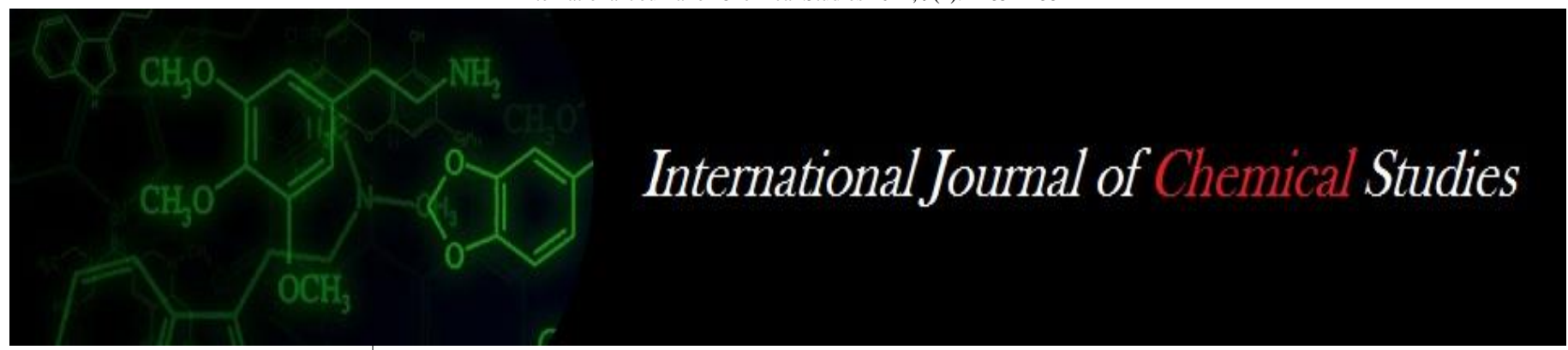

P-ISSN: 2349-8528

E-ISSN: 2321-4902

www.chemijournal.com

IJCS 2021; 9(1): 1485-1488

(C) 2021 IJCS

Received: 26-11-2020

Accepted: 28-12-2020

Dhanshree Bachkar

1. Department of Plant Pathology,

College of Agriculture, Dhule,

Maharashtra, India

2. Mahatma Phule Krishi

Vidyapeeth, Rahuri, Maharashtra,

India

\section{Sanjay Kolase}

Department of Plant Pathology and Agricultural Microbiology, Post Graduate Institute, Mahatma Phule Krishi Vidyapeeth, Rahuri, Maharashtra, Indi

\section{Mayur Bhujbal}

1. Department of Plant Pathology,

College of Agriculture, Dhule,

Maharashtra, India

2. Mahatma Phule Krishi

Vidyapeeth, Rahuri, Maharashtra,

India

\section{Chatur Thakare}

1. Department of Plant Pathology, College of Agriculture, Dhule,

Maharashtra, India

2. Mahatma Phule Krishi

Vidyapeeth, Rahuri, Maharashtra, India

Sandip Doltade

College of Agriculture, Pune,

Mahatma Phule Krishi Vidyapeeth,

Rahuri, Maharashtra, India

Mahadev Khatal

PhD Scholar, Post Graduate

Institute, Mahatma Phule Krishi

Vidyapeeth, Rahuri, Maharashtra, India

Navnath Daingade

1. Department of Plant Pathology,

College of Agriculture, Dhule,

Maharashtra, India

2. Mahatma Phule Krishi

Vidyapeeth, Rahuri, Maharashtra,

India

Corresponding Author:

Dhanshree Bachkar

1. Department of Plant Pathology,

College of Agriculture, Dhule,

Maharashtra, India

2. Mahatma Phule Krishi

Vidyapeeth, Rahuri, Maharashtra,

India

\section{In vitro efficacy of different fungicides against Fusarium incarnatum causing fruit rot of papaya (Carica papaya L.)}

\author{
Dhanshree Bachkar, Sanjay Kolase, Mayur Bhujbal, Chatur Thakare, \\ Sandip Doltade, Mahadev Khatal and Navnath Daingade
}

DOI: https://doi.org/10.22271/chemi.2021.v9.i1u.11437

\begin{abstract}
Papaya (Carica papaya L.) is an important and most widely grown fruit crop of both tropics and subtropics of the world, belonging to the family Caricaceae and ranks third in importance among fruits. Papaya fruits lose their market value due to damage caused by many fungi. These fungi by their prolific growth, deteriorates fruit quality. Among these, fruit rot caused by Fusarium incarnatum adversely affects the fruit quality, quantity and ultimately reduces the market value. The fruit rot of papaya causes enormous yield losses, often in field and markets. Detailed investigations on various aspects were carried out in the present study during 2019-20. The papaya fruits showing typical characteristic symptoms of fruit rot were collected from Pachkandil vegetable market, Dhule. Infected fruits exhibited water-soaked spots at stem-end portion and also showed softening and mummification of fruits. In severe cases, rotten fruit showed white creamy growth of the pathogen. The pathogen was isolated by standard tissue isolation method and purified by single spore technique. Pathogenicity of fungus was proved by following Koch's postulates. The fruit rot causal fungus was got identified by Agharkar Research Institute (An Autonomous body under the Department of Science and Technology, Govt. of India, G. G. Agarkar Road, Pune - 411 004) as Fusarium sp. aff. F. semitectum Berk \& Ravenel (Current nameFusarium incarnatum (Desm.) Sacc.) (ID.NO.3/426/2019/MYC/1135).

In vitro efficacy of fungicides, revealed that carbendazim $12 \%+$ mancozeb $63 \% \mathrm{WP}(0.2 \%)$ and hexaconazole $5 \%$ EC $(0.1 \%)$ completely inhibited mycelial growth of the test fungus, followed by carbendazim 50\% WP $(0.1 \%)$, propineb $70 \% \mathrm{WP}(0.25 \%)$, mancozeb $75 \% \mathrm{WP}(0.25 \%)$. Whereas, it was least with thiophanate methyl $70 \% \mathrm{WP}(0.1 \%)$.
\end{abstract}

Keywords: Papaya, Carica papaya L, Fusarium incarnatum, fungicides, inhibition

\section{Introduction}

Papaya (Carica papaya L.) is an important and most widely grown fruit crop of both tropics and subtropics of the world, belonging to the family Caricaceae and ranks third in importance among fruits. Carica is the largest of the four genera with 48 species, among which Carica papaya L. is most important and cultivated all over the world (Badillo, 1971 and Waller, 1992) $[3,11]$. The popularity of papaya fruit has made it ubiquitous in tropical and subtropical regions of the world. Papaya is the native of tropical America (Singh, 1990) ${ }^{[7,8]}$.

Papaya cultivation has become increasingly popular since, mid-nineteenth century because of its varied climatic tolerance and high nutritive values. The major papaya growing continents are Asia, South America, North Central America and Africa. About 65 per cent of the world's production is from South America. Another 35 per cent is from North Central America and Africa (Tasiwal and Benagi, 2008) ${ }^{[9]}$. In India, the papaya is grown for table purpose, papain and pectin extraction and concentrated in the state of Kerala, Orissa, West Bengal, Karnataka, Assam and Gujarat. In India, 1,38,400 ha area is covered under papaya with a production of $59,88,800$ metric ton with an average productivity of 43.3 metric ton per ha during 2017-18. In Maharashtra, 10,280 ha area is covered under papaya with a production of 4,08,000 metric ton with an average productivity of 39.71 metric ton per during 2017-18 (Anonymous, 2018) ${ }^{[2]}$.

The harvested papaya fruits always succumb to the infection by various pathogens causing fruit rot. Post-harvest diseases of papaya caused by fungi are responsible for causing losses to the tune of 45 per cent of their market value (Abeywickrama et al., 2012) ${ }^{[1]}$. Fruits are 
living entities and are highly perishable commodities that are affected by number of factors leading to be post-harvest spoilage and hence, post-harvest losses are major one. Postharvest diseases of fresh fruits are traditionally being controlled by synthetic chemical fungicides (Eckert and Ogawa, 1985) ${ }^{[5]}$. Papaya fruits are highly perishable in nature and it is very difficult to store for longer period, therefore, it needs immediate marketing and utilization.

Any physical damage like bruising or wound scratches to fruits makes them vulnerable/susceptible to many pathogens, resulting in heavy post-harvest losses. Reducing post-harvest losses in papaya fruit is an imperative aspect of research to find out the important pathogens attacking fruits during transit and storage, so as to advise appropriate management strategies and consequently to minimize post-harvest fruit losses in papaya. Considering these issues, present studies were undertaken on fruit rot of papaya,

\section{Material and Methods \\ Collection, isolation, purification, identification and pathogenicity of the pathogen}

Papaya fruits showing typical symptoms of fruit rot were collected from the Pachkandil vegetable market, Dhule, brought to the laboratory and subjected to tissue isolation of the pathogen.

Diseased papaya fruit tissues along with healthy tissues were cut and surface sterilized by dipping in 0.1 per cent mercuric chloride solution for one minute, followed by three successive washings with distilled sterile water. These pieces were aseptically placed on solidified Potato Dextrose Agar (PDA) medium $(20 \mathrm{ml})$ in Petri plates and incubated at $28{ }^{\circ} \mathrm{C}$ in BOD incubator, for seven days. The fungus was subcultured, purified by single spore isolation and maintained on PDA slant tubes.

Identification of the pathogen was carried out by studying the cultural and morphological characters. Microphotographs of mycelium and spore structure were taken with the help of digital camera. The pure culture was sent to Agharkar Research Institute (ARI), Pune for identification. They identified the pathogen as Fusarium sp. aff. F. semitectum Berk and Ravenel (Current Name - Fusarium incarnatum (Desm.) Sacc.), solely based on morphological characters.

For pathogenicity test conidial suspension was prepared $(4 \mathrm{x}$ $10^{6} \mathrm{cfu} / \mathrm{ml}$ ) by adding sterile distilled water to the inoculum. The fruits were inoculated with syringe by inoculating the conidial suspension, prepared from seven days old culture in sterile distilled water and incubated in moisture chamber to ensure successful infection. Observations were recorded for the appearance and development of the symptoms. After symptom development, reisolation was done from the artificially infected fruits and compared it with original culture for confirmation.

\section{In vitro efficacy of fungicides}

About six fungicides were evaluated in vitro against the test pathogen (Fusarium incarnatum), by applying Poison Food Technique (Nene and Thapliyal, 1982) ${ }^{[6]}$.

Required quantity of each test fungicide was added separately into molten and cool potato dextrose agar so as to get desired concentration, and $20 \mathrm{ml}$ of the poisoned medium was poured into sterile petri plates. Mycelial disc of $5 \mathrm{~mm}$ size from actively growing culture of the fungus were cut by sterile cork borer and one such disc was placed at the centre of each agar plate. Control was maintained without adding any fungicide to the medium. Each treatment was replicated thrice. Then such plates were incubated at room temperature for seven days and radial colony growth was measured. The efficacy of a fungicide was expressed as per cent inhibition of mycelial growth over control (Vincent, 1947) ${ }^{[10]}$.

$$
\mathrm{I}=\frac{(\mathrm{C}-\mathrm{T})}{\mathrm{C}} \times 100
$$

Where

$\mathrm{I}=$ Percent inhibition

$\mathrm{C}=$ Radial growth in control

$\mathrm{T}=$ Radial growth in treatment

Experimental details, as below -

1. Design - CRD (Complete Randomized Design)

2. Replications - 3

3. Treatment - Fungicides -7

Table 1: Treatment details

\begin{tabular}{|c|c|c|}
\hline Tr. No. & Treatments & Concentration \\
\hline $\mathrm{T}_{1}$ & Carbendazim 50\% WP & $0.1 \%$ \\
\hline $\mathrm{T}_{2}$ & Mancozeb 75\% WP & $0.25 \%$ \\
\hline $\mathrm{T}_{3}$ & Thiophanate methyl 70\% WP & $0.1 \%$ \\
\hline $\mathrm{T}_{4}$ & Carbendazim 12\% WP + Mancozeb 63\% WP & $0.2 \%$ \\
\hline $\mathrm{T}_{5}$ & Propineb 70\% WP & $0.25 \%$ \\
\hline $\mathrm{T}_{6}$ & Hexaconazole 5\% EC & $0.1 \%$ \\
\hline $\mathrm{T}_{7}$ & Control & - \\
\hline
\end{tabular}

Based on mean radial growth, the isolates were classified as highly sensitive, sensitive, moderately resistant, resistant and highly resistant to each fungicide as given below:

Table 2: The isolates were classified as highly sensitive, sensitive, moderately resistant, resistant and highly resistant to each fungicide as given below

\begin{tabular}{|c|c|c|}
\hline Sr. No. & Class & Percent inhibition over control \\
\hline 1. & Highly sensitive & $>90$ \\
\hline 2. & Sensitive & $>80-90$ \\
\hline 3. & Moderately resistant & $>70-80$ \\
\hline 4. & Less sensitive & $>50-70$ \\
\hline 5. & Non sensitive & $<50$ \\
\hline
\end{tabular}

\section{Results and Discussion}

The results (Table-1, Fig.-1, 2, 3) revealed that the test fungicides significantly inhibited mycelial growth of Fusarium incarnatum over control. However, Carbendazim $12 \%+$ Mancozeb 63\% WP and Hexaconazole 5\% EC completely inhibited mycelial growth (100\%) over control with no sporulation. These were followed by Carbendazim $50 \%$ WP $(65.16 \%)$ with scanty sporulation, Propineb $70 \%$ WP $(64.42 \%)$ with scanty sporulation, Mancozeb $75 \%$ WP $(45.69 \%)$ with moderate sporulation and Thiophanate methyl $70 \%$ WP (41.20\%) with moderate sporulation. 
Table 3: In vitro efficacy of fungicides against Fusarium incarnatum

\begin{tabular}{|c|c|c|c|c|c|}
\hline Tr. No. & Fungicides & Concentration (\%) & Mean colony diameter $(\mathrm{mm}) *$ & Sporulation & Percent inhibition (\%) \\
\hline $\mathrm{T}_{1}$ & Carbendazim 50\% WP & $0.1 \%$ & 31 & + & 65.16 \\
\hline $\mathrm{T}_{2}$ & Mancozeb 75\% WP & $0.25 \%$ & 48.33 & ++ & 45.69 \\
\hline $\mathrm{T}_{3}$ & Thiophanate methyl 70\% WP & $0.1 \%$ & 52.33 & ++ & 41.20 \\
\hline $\mathrm{T}_{4}$ & Carbendazim 12\% + Mancozeb 63\% WP & $0.2 \%$ & 0 & - & 100.0 \\
\hline $\mathrm{T}_{5}$ & Propineb $70 \% \mathrm{WP}$ & $0.25 \%$ & 31.66 & + & 64.42 \\
\hline $\mathrm{T}_{6}$ & Hexaconazole 5\% EC & $0.1 \%$ & 0 & - & 100.0 \\
\hline \multirow[t]{3}{*}{$\mathrm{T}_{7}$} & Control (Untreated) & - & 89 & +++ & - \\
\hline & S.E. \pm & & 0.57 & & \\
\hline & $\mathrm{CD}$ at $\overline{5 \%}$ & & 1.76 & & \\
\hline
\end{tabular}

* = Average of three replications, +++: Good sporulation, ++: Moderate sporulation, +: Scanty sporulation, -: No sporulation

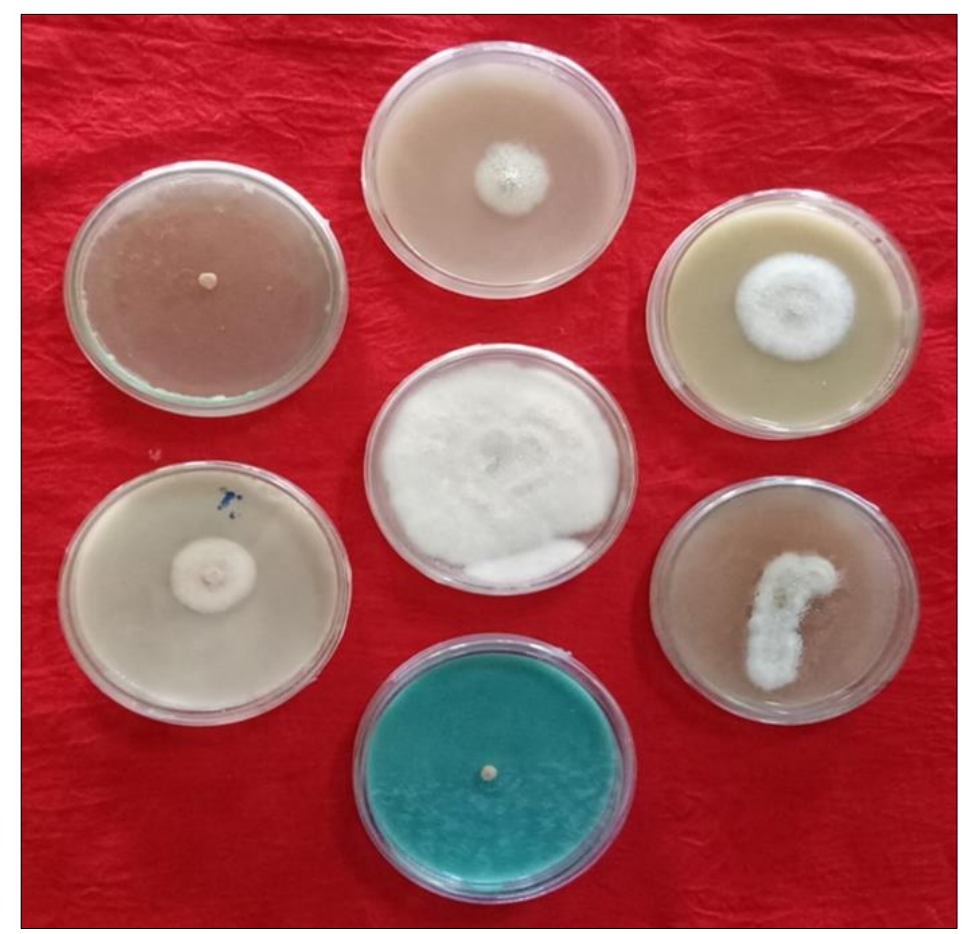

Fig 1: Plate 1, In vitro efficacy of fungicides against Fusarium incarnatum

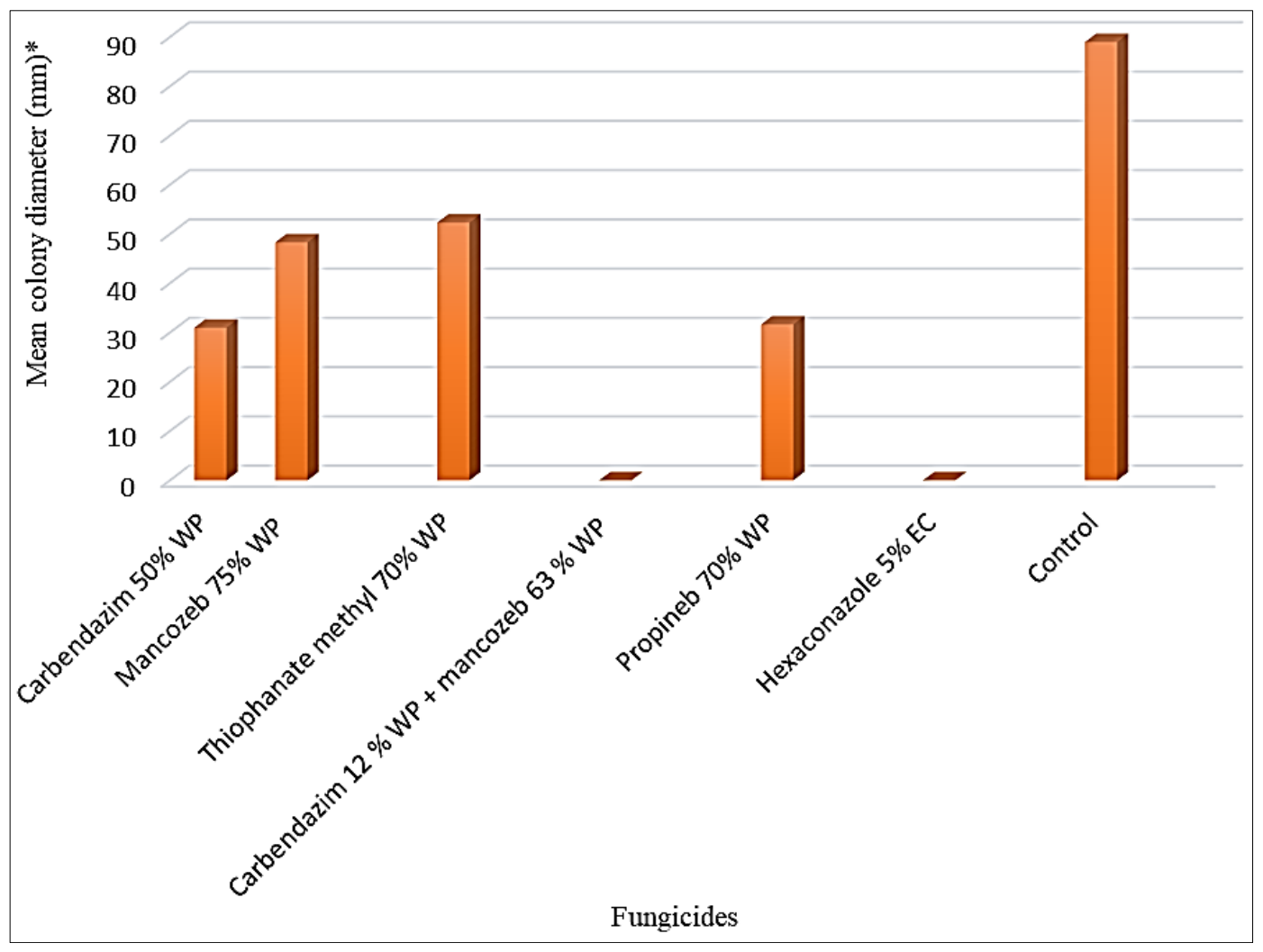

Fig 2: In vitro effect of fungicides on mycelial growth of Fusarium incarnatum 


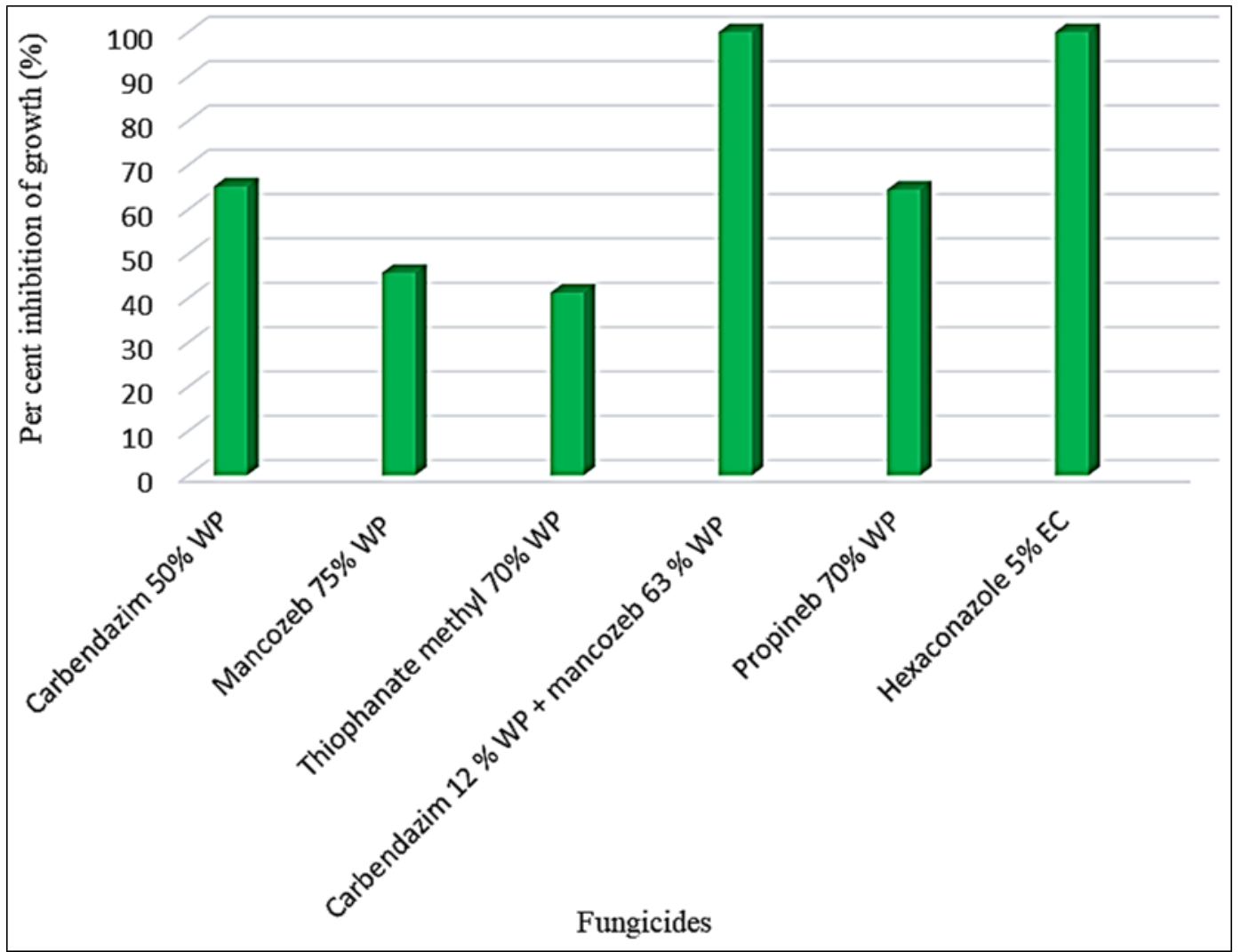

Fig 3: In vitro effect of fungicides on mycelial growth inhibition of Fusarium incarnatum

Similar results were earlier reported by Singh $(2011)^{[7,8]}$, who reported complete mycelial growth inhibition of $F$. moniliforme (banana fruit rot) with Benomyl, Carbendazim $12 \%+$ Mancozeb $63 \%$ WP, Thiophanate methyl, Carbendazim and Propiconazole. Damaram (2012) ${ }^{[4]}$ reported complete mycelial growth inhibition of $F$. pallidoroseum causing tomato fruit rot with Carbendazim 12\% + Mancozeb $63 \%$ WP, Hexaconazole 5\% + Captan 70\% WP, Carbendazim and Propiconazole.

\section{Conclusion}

Hence, from ongoing results and discussion, it is concluded that in vitro testing of fungicides against Fusarium incarnatum revealed that Carbendazim 12\% + Mancozeb 63\% WP and Hexaconazole 5\% EC completely inhibited the mycelial growth (100\%) with no sporulation of the $F$. incarnatum, followed by Carbendazim 50\% WP $(65.16 \%)$ with scanty sporulation, Propineb $70 \%$ WP (64.42\%) with scanty sporulation and Mancozeb 75\% WP (45.69\%) with moderate sporulation.

\section{Acknowledgements}

The authors wish to thank Head and Faculty members, Department of Plant Pathology Section, College of Agriculture, Dhule for their valuable encouragement and kind assistance.

\section{References}

1. Abeywickrama K, Wijerathna C, Rajapaksha N, Sarananda K, Kannan S. Disease control strategies for extending storage life of papaya (Carica papaya), cultivars "Red Lady" and "Rathna". Ceylon J Sci 2012;41(1):27-34.

2. Anonymous. Horticultural statistics at a glance 2018 .
3. Badillo VM. Monografia de la familie Caricaceae. Associacion de Professors, Universidad Central de Venezuela, Maracay, Venezuela 1971.

4. Damaram V. Investigations on Fusarium Fruit Rot [Fusarium pallidoroseum (Cooke) Sacc.] of Tomato (Lycopersicon esculentum Mill) and its Management. M. Sc. Thesis, AAU, Anand 2012.

5. Eckert JW, Ogawa JM. The chemical control of medicinal plants on spore germination of some Fusarium species. Karnataka. J Agric. Sci 1985;13:153-154.

6. Nene YL, Thapliyal PN. Fungicides in Plant Diseases Control. Oxford and IBH Pub. Co. Pvt. Ltd., New Delhi 1982, P163.

7. Singh ID. Papaya. Oxford and IBH Pub. Co. Pvt. Ltd. New Delhi 1990, P192.

8. Singh KB. Studies on Fusarium fruit rot (Fusarium moniliforme Sheldon) of banana (Musa paradisiaca L.) and its management. M.Sc. Thesis, AAU, Anand 2011.

9. Tasiwal V, Benagi VI. Studies on anthracnose-a postharvest disease of papaya. M. Sc. Thesis, UAS, Dharwad 2008.

10. Vincent JM. Distortion of fungal hyphae in the presence of certain inhibitors. Nature 1947;150:850.

11. Waller JM. Colletotrichum diseases of perennial and other cash crops. Colletotrichum: Biology. Pathology and Control (Edt. J. A. Bailey and M. J. Jegar) CAB publication UK 1992, P167-185. 